\title{
Late Paleoproterozoic sedimentary rock-hosted stratiform copper deposits in South China: their possible link to the supercontinent cycle
}

\author{
Xin-Fu Zhao • Mei-Fu Zhou • Jian-Wei Li • Liang Qi
}

Received: 26 January 2012 / Accepted: 3 October 2012 /Published online: 17 October 2012

(C) The Author(s) 2012. This article is published with open access at Springerlink.com

\begin{abstract}
Giant sedimentary rock-hosted stratiform copper (SSC) deposits commonly occur in rift environments, temporally coincident with the breakup of the Rodinia and Pangea supercontinents. However, whether or not such deposits have also formed during the breakup of the Paleoproterozoic Columbia supercontinent is not well known. A group of dolostone-hosted $\mathrm{Cu}$ deposits in late Paleoproterozoic rift-related sedimentary sequences of the Dongchuan Group, South China, form one of the largest SSC districts in the world. Being one of the largest SSC deposits in the region, the Yinmin deposit has stratiform $\mathrm{Cu}$ orebodies intruded by dolerite dykes. One dyke has a SIMS zircon $\mathrm{U}-\mathrm{Pb}$ age of $1,701 \pm 28 \mathrm{Ma}$, slightly younger than the orehosting strata with a zircon $\mathrm{U}-\mathrm{Pb}$ age of $1,742 \pm 13 \mathrm{Ma}$ for a tuff unit. Six chalcopyrite and bornite separates from stratiform orebodies contain highly radiogenic Os and extremely
\end{abstract}

Editorial handling: C.Y. Wang

Electronic supplementary material The online version of this article (doi:10.1007/s00126-012-0445-0) contains supplementary material, which is available to authorized users.

X.-F. Zhao • M.-F. Zhou ( $\bowtie)$

Department of Earth Sciences, University of Hong Kong,

Hong Kong, SAR, China

e-mail:mfzhou@hku.hk

J.-W. Li

State Key Laboratory of Geological Processes and Mineral

Resources, China University of Geosciences,

Wuhan, China 430074

J.-W. Li

Faculty of Earth Resources, China University of Geosciences,

Wuhan, China 430074

L. Qi

State Key Lab of Ore Deposit Geochemistry,

Institute of Geochemistry, Chinese Academy of Sciences,

Guiyang, China 550002 low common Os and yield a weighted mean Re-Os model age of $1,666 \pm 82 \mathrm{Ma}$ and a ${ }^{187} \mathrm{Os}-{ }^{187} \mathrm{Re}$ errorchron age of $1,585 \pm 100 \mathrm{Ma}$. The present zircon $\mathrm{U}-\mathrm{Pb}$ and sulfide $\mathrm{Re}-\mathrm{Os}$ ages thus constrain the timing of the mineralization at $\sim$ 1,700 Ma. The Yinmin deposit and, by inference, other SSC deposits in the region, arguably represent a large-scale SSC mineralization event during the late Paleoproterozoic. The formation of these deposits was coeval with the initial breakup/fragmentation of the Columbia supercontinent. This study highlights the temporal and likely genetic links between large-sized SSC deposits and the supercontinent cycle.

Keywords Dongchuan-type Cu deposit · Late

Paleoproterozoic $\cdot$ Rift basin $\cdot$ South China $\cdot$ Supercontinent cycle

\section{Introduction}

Sedimentary rock-hosted stratiform $\mathrm{Cu}$ deposits commonly occur in intracontinental sedimentary basins, a setting favorable for the formation of red-bed sequences and hence the development of highly oxidized, saline basinal brines (Kirkham 1989; Hitzman et al. 2005). Movement of oxidized, cupriferous basinal fluids across a reduction front, which results in dramatic changes in redox state of the fluids, has been suggested as the main mechanism for large-scale sulfide precipitation (Brown 1997; Hitzman et al. 2005, 2010). Large-scale production of such oxidized fluids may not have been possible until the early Paleoproterozoic when the global atmosphere and oceans became oxidized (Holland 2005; Hitzman et al. 2010).

Failed continental rifts, which subsequently became intracratonic basins filled with syn-rift red-bed sequences, have been considered as the most favorable tectonic setting for SSC deposits (e.g., Kirkham 1989; Brown 1997; 
Hitzman et al. 2010). Available data show that giant SSC deposits formed in late Neoproterozoic and late Paleozoic basins, temporally coincident with the breakup of the Rodinia and Pangea supercontinents, respectively. Hitzman et al. (2010) proposed that the formation of large-scale SSC deposits is a combined consequence of continental breakup, evaporite deposition, and global glaciation. However, there is no well-defined example that SSC deposits formed associated with the breakup of the late Paleoproterozoic Columbia supercontinent.

Numerous dolostone-hosted $\mathrm{Cu}$ deposits, traditionally known as "Dongchuan-type" $\mathrm{Cu}$ deposits in the Chinese literature (e.g. Ran 1989; Gong et al. 1996), are developed in the late Paleoproterozoic Dongchuan Group in the Kangdian region, Yangtze Block, South China. These deposits share mineralization features typical of SSC deposits (Ran 1989; Hua 1990a; Gong et al. 1996; Zhao et al. 2012). But a major problem of better understanding of these deposits is the lack of precise isotopic ages which hamper to understand the geodynamic setting of the ore mineralization.

Recent studies have shown that the Yangtze Block was likely a component of the Columbia supercontinent (Zhang et al. 2006; Sun et al. 2008; Zhao et al. 2010). The Dongchuan Group has been suggested to have formed in an intracontinental rift basin likely during the initial breakup/fragmentation of the Columbia supercontinent (Zhao et al. 2010). In this paper, we present sulfide Re-Os dates of stratiform ores and a zircon $\mathrm{U}-\mathrm{Pb}$ age of a dolerite intruding the stratiform orebody in order to constrain the timing of $\mathrm{Cu}$ mineralization. The new dataset indicates a large-scale SSC metallogenic event in the late Paleoproterozoic and permit a link between pervasive stratiform $\mathrm{Cu}$ mineralization in South China and the initial fragmentation of the Columbia supercontinent.

\section{Geological background}

The Yangtze Block is bounded by the Tibetan Plateau to the west and by the Cathaysia Block to the southeast, and is separated from the North China Craton by the QinlingDabie-Sulu Orogen to the north (Fig. 1a). The Precambrian Yangtze Block consists predominantly of Meso- to Neoproterozoic strata and Neoproterozoic igneous rocks. Archean and Paleoproterozoic rocks were only previously known in the northern part of the Yangtze Block. They comprise $\sim 2.9$ Ga tonalitic-trondhjemitic-granitic gneisses, which underwent granulite facies metamorphism during the period of 2.03 to $1.97 \mathrm{Ga}$ (Zhang et al. 2006; Wu et al. 2008) and were intruded by A-type granites and mafic dykes at $\sim 1.85 \mathrm{Ga}$ (Peng et al. 2009; Xiong et al. 2009). These Paleoproterozoic metamorphic and magmatic events have been linked to the assembly and breakup of the Columbia supercontinent (Zhang et al. 2006; Sun et al. 2008; Wu et al. 2008).

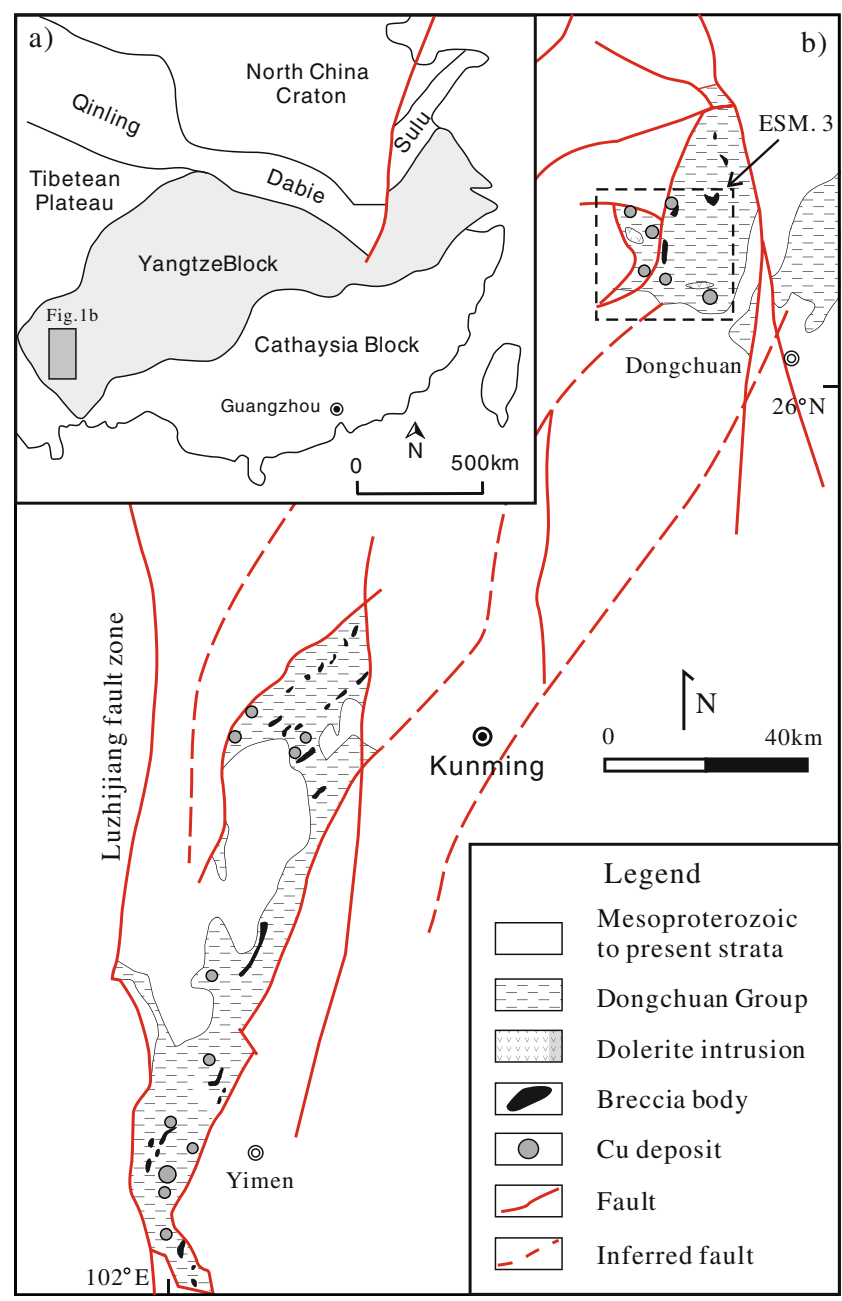

Fig. 1 a Simplified tectonic map showing the study area in the Yangtze Block; b a geological map showing the distribution of the Dongchuan Group and the stratiform $\mathrm{Cu}$ deposits in the Kangdian region, SW China (modified from Wu et al. 1990)

In the western Yangtze Block, Proterozoic strata are widespread in the Kangdian region and are mainly controlled by NS- to NNE-trending faults (Fig. 1b). The Paleoproterozoic Dongchuan Group comprises, from the base to the top, the Yinmin, Luoxue, E’touchang, and Luzhijiang Formations (Fms) (ESM 1). The Yinmin Fm is mainly composed of hematite-bearing purplish-red siltstone and sandstone, with basal conglomerate in places (ESM 1 and $2 \mathrm{a}-\mathrm{b})(\mathrm{Wu}$ et al. 1990). These rocks are thought to be the oldest continental red-bed units in the Yangtze Block (Hua 1990b; Wu et al. 1990; Zhao et al. 2010). The uppermost part of the Yinmin Fm consists of intercalated siltstone and dolostone that are transitional to the thick-layered basal dolostone of the Luoxue Fm. Conformably overlying the Yinmin Fm (ESM 1), the Luoxue Fm consists of thick layers of grayish-white dolostone and argillo-arenaceous dolostone. The contact between the Yinmin and Luoxue Fms is generally sharp (ESM 2a) suggesting a rapid marine transgression. Lamellar, cylindrical, 
and spherical stromatolites (ESM 2c) are common in the basal part of the Luexue Fm (Gong et al. 1996). The E'touchang Fm is composed of black shale with minor amounts of limestone and siltstone. Gray dolostone, argillaceous dolostone, and subordinate interbeds of limestone and siltstone dominate the Luzhijiang Fm.

The strata of the Dongchuan Group are intruded by numerous breccia bodies, regionally known as the Yinmin Breccia (Wu et al. 1990) (Fig. 1b). These breccia bodies range from a few meters to several kilometers in length. The breccias are both clast- and matrix-supported and contain rounded to angular fragments of Yinmin Fm siltstone and sandstone (ESM 2d), with less common clasts from the Luoxue and Etouchang Fms and rare mafic igneous clasts. The fragments range from $<1 \mathrm{~cm}$ to tens of meters in diameter. They are cemented by a matrix of hydrothermal dolomite, ankerite, albite, quartz, potassium feldspar, and biotite and pulverized rocks. The formation of the Yinmin Breccias was attributed to the former presence of salt (Ruan et al. 1991) which was thought to have originally been present in the lower Yinmin Fm.

Tuffaceous volcanic rocks are locally present in the Yinmin Fm (ESM 1). Zircons from a tuff unit of the Yinmin Fm have a LA-ICPMS U-Pb age of 1,742 $\pm 13 \mathrm{Ma}$ (Zhao et al. 2010). Detrital zircons from the Yinmin Fm have U-Pb ages of $\sim 3.5$ to $\sim 1.78 \mathrm{Ga}$ (Zhao et al. 2010). Chang et al. (1997) reported a whole-rock $\mathrm{Pb}-\mathrm{Pb}$ isochron age of $1,716 \pm 56 \mathrm{Ma}$ for dolostone of the Luoxue Fm (ESM 1). Thus, the available age data indicate that the lower parts of the Dongchuan Group formed during the late Paleoproterozoic. The Dongchuan Group is intruded by numerous late Paleoproterozoic dolerite intrusions and is unconformably overlain by Meso- to Neoproterozoic, and Mesozoic carbonate and clastic sedimentary rocks.

\section{Sedimentary rock-hosted stratiform copper deposits in the Kangdian region}

Sediment-hosted stratiform copper deposits are well developed in the Dongchuan Group of the Kangdian region. They are best represented by those in the Dongchuan district, including the Tangdan, Luoxue, and Yinmin deposits (ESM 3). The cumulative tonnage in the Kangdian region is estimated to be in excess of $600 \mathrm{Mt}$ at $\sim 1 \% \mathrm{Cu}$ based on old exploration data (Gong et al. 1996). It would rank the Kangdian region as the world's 3rd or 4th largest sedimenthosted stratiform copper district after the Central African Copperbelt and the Kupferschiefer (Zhao et al. 2012).

The Yinmin deposit is one of the largest stratiform $\mathrm{Cu}$ deposits in the region, with approximately $50 \mathrm{Mt}$ contained copper. Copper orebodies are hosted in dolostone of the Luoxue Fm and are roughly parallel to stratification. They are mostly located at the base of the Luoxue Fm, immediately above the Yinmin Fm (ESM 4). Individual ore bodies are usually several to tens of meters in thickness, but can extend for more than $10 \mathrm{~km}$ along the lithological interface. Ore bodies are commonly crosscut or disrupted by faults and dolerite dykes (Fig. 2 and ESM 4).

Sulfides are preferentially localized along the laminations and/or fractures of the host dolostone (ESM 5a and b). Chalcopyrite and bornite are the dominant ore minerals, occurring as disseminations, veinlets, and less commonly stockworks. The orebodies are more or less overprinted by supergene chalcocite and digenite. Copper sulfides are associated with authigenic quartz and ankerite (ESM 5c and d), which are normally coarser than the carbonate minerals of the host dolostone.

Siliciclastic and tuffaceous rocks at the deposit scale have been widely affected by hydrothermal alteration consisting of quartz, ankerite, K-feldspar, sericite (muscovite), albite, biotite, chlorite, hematite, apatite, and tourmaline. Hydrothermal alteration of the dolostone is best represented by $\mathrm{K}$ feldspar overprinted by quartz and ankerite. Precipitation of copper sulfides was closely associated with silicification.

\section{Isotopic ages}

Zircons from a dolerite dyke and ore-hosting strata were measured for $\mathrm{U}-\mathrm{Pb}$ isotope dates, and $\mathrm{Cu}$-sulfide separates from stratiform ores were analyzed for Re-Os ages. Analytical methods are described in EMS 6.

\section{Zircon $\mathrm{U}-\mathrm{Pb}$ ages}

Siltstone of the Yinmin Formation (YN11-05) and a dolerite dyke (DC-13) crosscutting the stratiform $\mathrm{Cu}$ orebody (Fig. 2a) at the 2,472-m-level adit of the Laoxinshan segment in the Yinmin mine were collected for zircon $\mathrm{U}-\mathrm{Pb}$ dating. The dyke with over $100 \mathrm{~m}$ in width is the largest one in the mine district. It nearly vertically intruded the orehosting strata and the stratiform $\mathrm{Cu}$ orebody (Fig. 2a). Stratiform $\mathrm{Cu}$ orebodies were disrupted by the dyke suggesting that it postdates ore mineralization.

Zircons of the dolerite dyke are light brownish to slightly black, prismatic in shape, and 80-150 $\mu \mathrm{m}$ long with length/ width ratios of 1.5-2.5. They do not have obvious zoning in $\mathrm{CL}$ images. Most grains show black fractures under transmitted light, likely resulting from radiation damage given that they have high Th up to $7,325 \mathrm{ppm}$ and $\mathrm{U}$ up to 1,880 ppm (Table 1). Five analyses (spots 1, 2, 6, 9, and 13) have nearly concordant $\mathrm{U}-\mathrm{Pb}$ ages with a weighted mean ${ }^{207} \mathrm{~Pb} /{ }^{206} \mathrm{~Pb}$ age of $1,701 \pm 28 \mathrm{Ma}(2 \sigma$, Fig. $3 \mathrm{a})$. Spots $3,7,8$, and 10-12 have a large proportion of common $\mathrm{Pb}$ (>4\%) and extremely high Th (2,288-7,325 ppm) and U (329-1,697 ppm), possibly resulting from overprint by later 
Fig. 2 a A simplified geological map of the level 2,472 adit showing a dolerite dyke intruding the stratiform $\mathrm{Cu}$ orebodies; the crosscutting relationship has been observed at different levels of adits, and the intrusion of the dyke postdated $\mathrm{Cu}$ mineralization; b Field photo showing the dolerite dyke intruding the rocks of the Yinmin Fm; c Typical texture of the dolerite dyke composed of plagioclase, clinopyroxene, and Fe-oxides
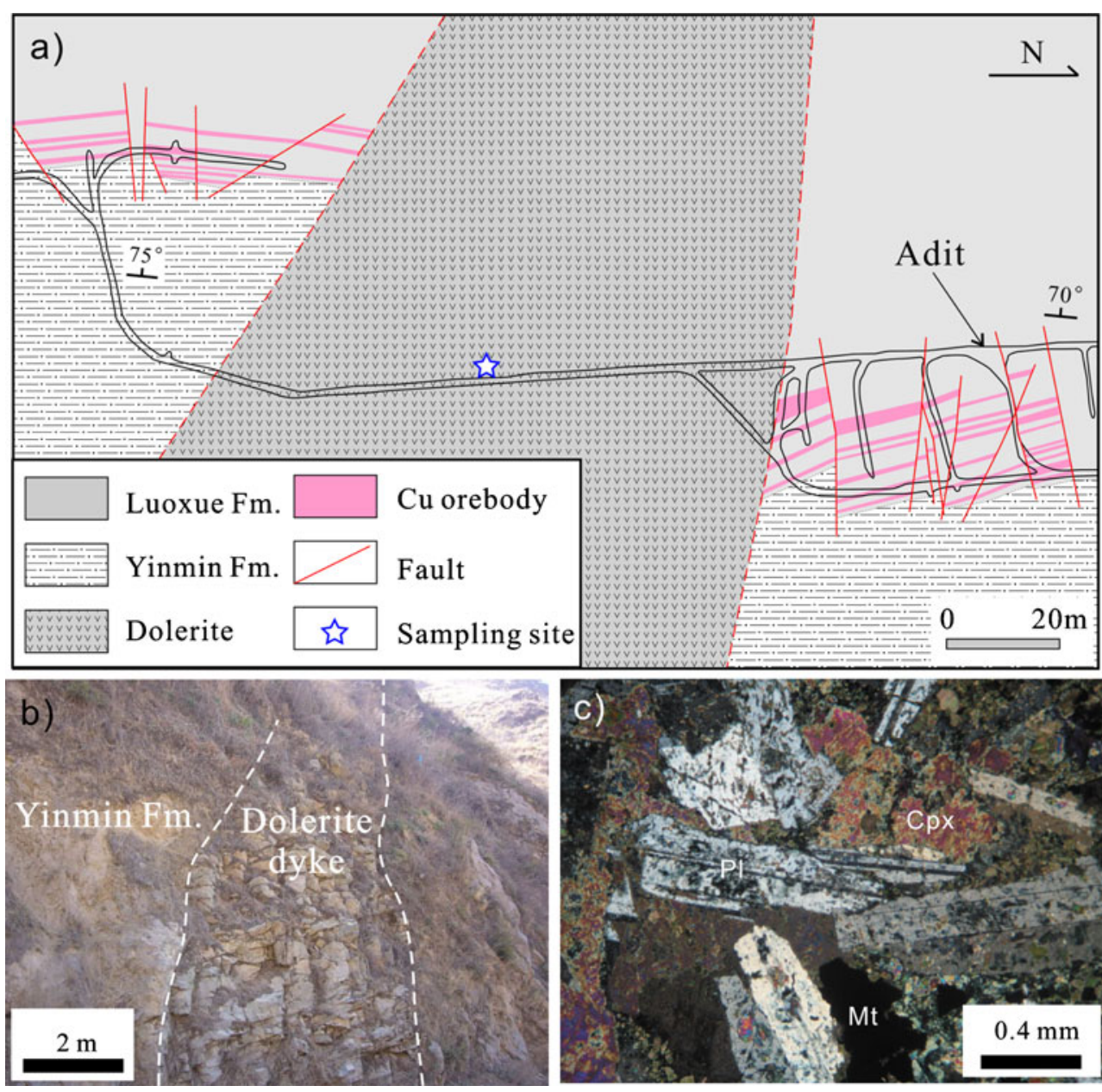

U-rich hydrothermal fluids. Analyses of these grains yielded meaningless $\mathrm{U}-\mathrm{Pb}$ ages and were not included in the age calculation. The remaining seven analyses plot on a discordant line and give an upper intercept age of 1,706 $19 \mathrm{Ma}$ (Fig. 3a) and a lower intercept at $236 \pm 95 \mathrm{Ma}$. The weighted mean age of the concordant grains $(1,701 \pm 28 \mathrm{Ma})$ is indistinguishable from the upper intercept age and is interpreted as the emplacement age of the dolerite dyke.

Detrital zircons of sample YN11-05 from the Yinmin Formation are mostly short-prismatic, brown to transparent, and sub-angular to sub-rounded. Most zircons are ca. 50$100 \mu \mathrm{m}$ long and have oscillatory zoning, but some show faint and broad zoning or no obvious zoning in CL images. Most analyses do not yield concordant ages possibly due to $\mathrm{Pb}$ loss. Their ${ }^{207} \mathrm{~Pb} /{ }^{206} \mathrm{~Pb}$ ages range from 1,850 to 2,902 Ma (Fig. 3b and ESM 7), and the majority of ages falls into three major populations at ca. 1,850-1,920 Ma, 2,250-2,350 Ma, and 2,650-2,750 Ma. The age results are consistent with those obtained from the strata of the Yinmin Formation (Zhao et al. 2010). When combined, the detrital zircons have three age peaks at $\sim 1,850 \mathrm{Ma}, \sim 2,300$, and $\sim 2,700 \mathrm{Ma}$ (Fig. 3c).
Sulfide Re-Os ages

Rhenium-osmium isotopic data of nine chalcopyrite and bornite separates are summarized in ESM 8. They have ${ }^{187} \mathrm{Re}$ ranging from 8.4 to $564 \mathrm{ppb}$ and ${ }^{187} \mathrm{Os}$ from 0.26 to $15.1 \mathrm{ppb}$. Due to the high radiogenic ${ }^{187}$ Os and very low common Os (less than $0.024 \mathrm{ppb}$ ), these samples have extremely large ${ }^{187} \mathrm{Re}^{188} \mathrm{Os}(>7,800)$ and ${ }^{187} \mathrm{Os} /{ }^{188} \mathrm{Os}$ ratios, and can be regarded as low-level highly radiogenic (LLHR) sulfides (Stein et al. 2000). Consequently, these samples can be used to calculate Re-Os model ages like those of molybdenite and an ${ }^{187} \mathrm{Re}$ vs ${ }^{187} \mathrm{Os}$ isochron plot is applied instead of ${ }^{187} \mathrm{Re} /{ }^{188} \mathrm{Os}$ vs ${ }^{187} \mathrm{Os} /{ }^{188} \mathrm{Os}$ due to the large uncertainties of ${ }^{188} \mathrm{Os}$. Two samples, YMZ-51 and YMZ-53, have geologically meaningless model ages of 2,332 and 2,513 Ma, which are much older than the orehosting strata of $\sim 1,740 \mathrm{Ma}$. The sample YMZ-81 has a relatively young model age of $1,424 \pm 13 \mathrm{Ma}$. The other six samples have model ages ranging from 1,571 to $1,822 \mathrm{Ma}$ with a weighted average model age of $1,666 \pm 82 \mathrm{Ma}(2 \sigma)$ and define a ${ }^{187} \mathrm{Re} v \mathrm{vs}{ }^{187} \mathrm{Os}$ errorchron age of $1,585 \pm 100 \mathrm{Ma}(2 \sigma$, Fig. 4). 


\section{Discussion}

Ages of the SSC deposits in Dongchuan district

Mineralization ages of the SSC deposits in the Kangdian region were poorly constrained, largely due to the lack of minerals that are suitable for traditional isotopic dating method. Previous geochronological studies, mostly using sulfide $\mathrm{Pb}-\mathrm{Pb}$ dating, yielded ages spanning from 1.7 to 0.7 Ga (e.g., Gong et al. 1996). Qiu et al. (2002) and Ye et al. (2004) attempted to date the mineralization using ${ }^{40} \mathrm{Ar} /{ }^{39} \mathrm{Ar}$ analysis of inclusion fluids extracted from quartz, yielding ages mostly between $\sim 780$ and $\sim 700 \mathrm{Ma}$. These ${ }^{40} \mathrm{Ar} /{ }^{39} \mathrm{Ar}$ ages led them to conclude that the stratiform $\mathrm{Cu}$ deposits were genetically related to the extensive Neoproterozoic magmatism and metamorphism in the Yangtze Block. However, fluid inclusions in quartz could have been derived from multiple sources or trapped during multiple stages and are likely affected by secondary fluid inclusions. The Kangdian region experienced a pervasive tectonothermal event at the Neoproterozoic, when ${ }^{40} \mathrm{Ar} /{ }^{39} \mathrm{Ar}$ dates of biotite and amphiboles have been reset (e.g., Zhao and Zhou 2011). Thus, these ${ }^{40} \mathrm{Ar} /{ }^{39} \mathrm{Ar}$ ages of quartz fluid inclusions previously published also likely reflect such a thermal overprint event, rather than the true age of mineralization.

Zircon $\mathrm{U}-\mathrm{Pb}$ isotope analysis is the most robust method for geochronological study. The geological relationship between the dolerite dykes and the ore bodies provides an ideal opportunity to bracket mineralization ages. Zhao et al. (2010) obtained a zircon U-Pb age of $\sim 1,742 \pm 13 \mathrm{Ma}$ for volcanic rocks of the Yinmin Fm and detrital zircons from the Yinmin Fm gave the youngest age of $\sim 1,780 \mathrm{Ma}$ (Fig. 3b). These zircon ages thus suggest that the orehosting strata were formed at $\sim 1,740 \mathrm{Ma}$. The strata were intruded by numerous dolerite dykes and the largest one was chosen for zircon $\mathrm{U}-\mathrm{Pb}$ dating by this study. This dyke structurally crosscutting $\mathrm{Cu}$ orebodies (Fig. 2a) has been observed at different levels of underground workings. It disrupts the continuity of the orebody and postdates $\mathrm{Cu}$ mineraliztion. Therefore, the dolerite dyke with the age of $1,701 \pm 28$ Ma provides a minimum age constraint on the $\mathrm{Cu}$ mineralization.

Moreover, this study obtained $\mathrm{Re}-\mathrm{Os}$ ages for $\mathrm{Cu}$ sulfides from the stratiform orebodies that provide additional information about the timing of sulfide mineralization. Because chalcopyrite and bornite from the Yinmin mine have high radiogenic ${ }^{187}$ Os and extremely low common Os, their $\mathrm{Re}-\mathrm{Os}$ model ages can provide accurate isotopic dates. Two chalcopyrite samples (YMZ-51 and YMZ-53) have indeed impossible model ages of $\sim 2,513$ and $\sim 2,332 \mathrm{Ma}$, much older than the $\sim 1,740$ Ma country rocks. Obviously, these two model ages are geologically meaningless. However, the molybdenite standard HLP has the age of $223.0 \pm 2.1 \mathrm{Ma}$ 

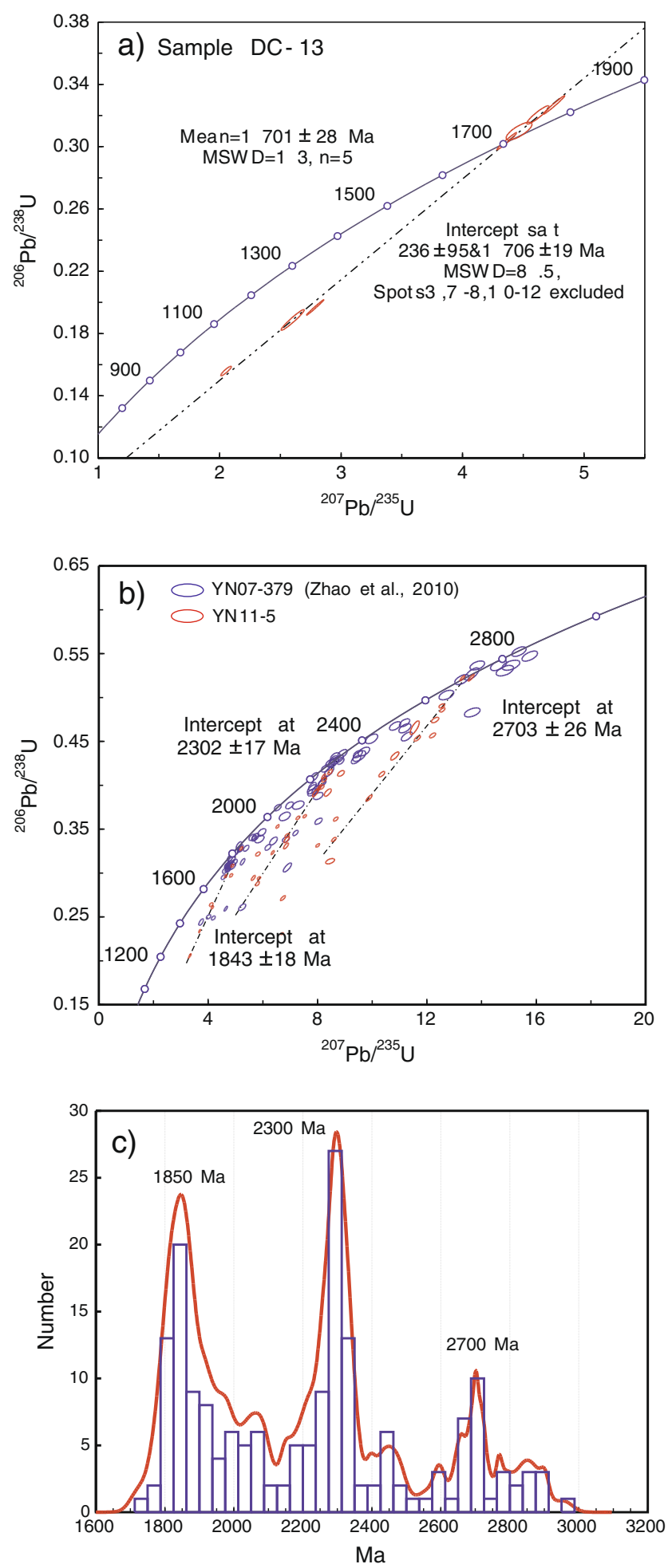

Fig. 3 Zircon $\mathrm{U}-\mathrm{Pb}$ concordia diagram for a dolerite dyke (a) and siltstone of the Yinmin Formation (b) from the Yinmin mine; c Histogram of $\mathrm{U}-\mathrm{Pb}$ ages of detrital zircons from the Yinmin Formation showing peaks at 1,850 Ma, 2,300 Ma, and 2,700 Ma

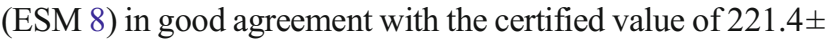
5.6 Ma (Du et al. 2004), suggesting that our analytical

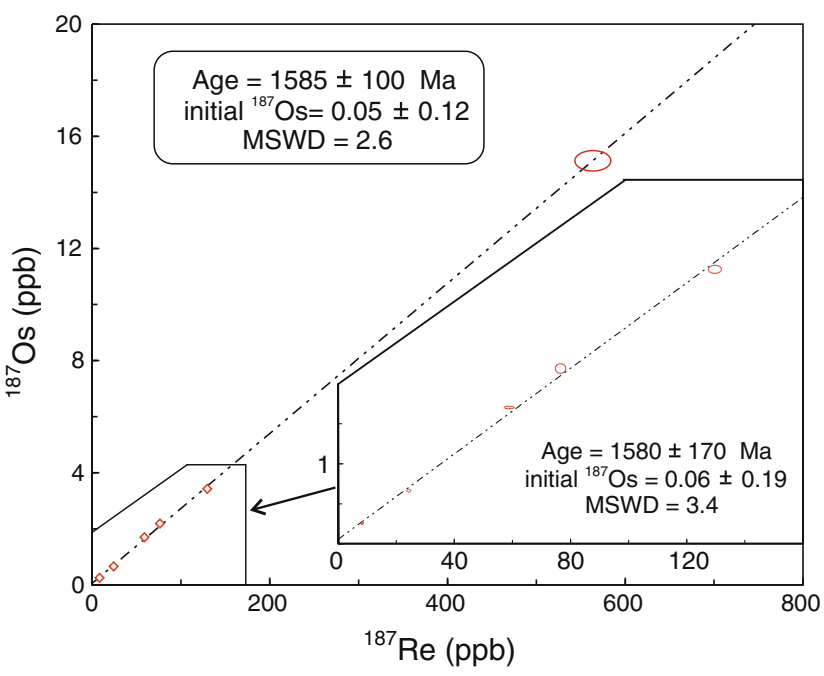

Fig. $4{ }^{187} \mathrm{Re}-{ }^{187} \mathrm{Os}$ plot of chalcopyrite and bornite separates from stratiform ore in the Yinmin deposit. The insert figure shows the fivepoint regression without the most radiogenic sample

procedure is correct. The impossibly old model ages can be explained by addition of radiogenic Os or loss of Re from the sulfides. In consideration of their extremely low common Os concentrations, it is less likely that the chalcopyrite could gain extra Os from outside. We thus suggest that loss of Re is responsible for the apparently older ages of the two chalcopyrite samples. Based on the same argument, chalcopyrite sample YMZ-81 with a much younger model age of $\sim 1,424 \mathrm{Ma}$ is likely due to the addition of Re. Our study thus suggests that Re was likely remobilized in some chalcopyrite samples from the Yinmin deposit. The other six samples with model ages ranging from 1,571 to $1,822 \mathrm{Ma}$ are hence considered to be less affected by Re remobilization and are used for age calculation in this study.

A prerequisite to define an isochron age is that all samples have the same initial isotope compositions and that the isotope system remains closed after mineral formation. For the ${ }^{187} \mathrm{Re}$ vs ${ }^{187}$ Os plot used for the LLHR sulfides, it requires that $\mathrm{Re}$ and Os remain immobile after sulfide formation. Therefore, the three samples that may have been affected by Re remobilization are discarded. The other six samples less affected by remobilization have an errorchron age of $1,585 \pm 100 \mathrm{Ma}$, which is in agreement with their weighted average Re-Os model age of 1,666 $\pm 82 \mathrm{Ma}$. Both ages have large uncertainties, but they provide an additional constraint on the timing of ore formation. Both ages are broadly consistent with the SIMS zircon U-Pb age of $1,701 \pm 28 \mathrm{Ma}$ for a dolerite dyke that crosscuts the stratiform $\mathrm{Cu}$ orebody.

In summary, the $\mathrm{Re}-\mathrm{Os}$ and $\mathrm{U}-\mathrm{Pb}$ isotopic data constrain the age of the $\mathrm{Cu}$ mineralization of the Yinmin deposit at $\sim 1,700 \mathrm{Ma}$, i.e., shortly after deposition of the ore-hosting strata at $\sim 1,740 \mathrm{Ma}$. This age is consistent with textural evidence that sulfide mineralization in the Dongchuan 
district took place during early diagenesis (Zhao et al. 2012). As the SSC deposits in the Dongchuan district have similar mineralization styles, it is also inferred that these deposits have a common origin in the late Paleoproterozoic.

Possible link to the Columbia supercontinent

Collisional events at 2.1 to 1.8 Ga have been recorded in a number of Precambrian cratons and are thought to be related to the assembly of the Paleoproterozoic Columbia supercontinent (Rogers and Santosh 2002; Zhao et al. 2002). In the traditional reconstruction models (Rogers and Santosh 2002; Zhao et al. 2002), the Yangtze Block is not included in the Columbia supercontinent, due to the lack of geological and geochronological data for that time. However, recent studies reveal that the Yangtze Block may have been involved in this global Paleoproterozoic orogenic event (Zhang et al. 2006; Sun et al. 2008; Wu et al. 2008; Peng et al. 2009; Zhao et al. 2010). For example, the 2.05-1.9 Ga magmatism and granulitic metamorphism in the northern Yangtze Block have been interpreted to be a response of the assembly of the Columbia supercontinent (Zhang et al. 2006; Sun et al. 2008; Wu et al. 2008). The 2.05-1.95 Ga detrital zircons of metamorphic origin have been identified in the Dongchuan Group, also implying that the orogenic event may have taken place in the Yangtze Block (Zhao et al. 2010).

The Columbia supercontinent was likely transformed to an extensional setting at 1.75 to $1.6 \mathrm{Ga}$ as indicated by the occurrence of mafic dyke swarms, anorthosites, rapakivi granites, and intracontinental rift basins (e.g. Zhao et al. 2004, 2009; Peng et al. 2008). In the western Yangtze Block, the Dongchuan Group with a zircon $\mathrm{U}-\mathrm{Pb}$ age of $1,742 \pm 13 \mathrm{Ma}$ has been considered to have formed in a continental rift basin (Hua 1990b; Wu et al. 1990; Zhao et al. 2010). The continental rift setting is also indicated by the presence of $\sim 1.70$ to $1.65 \mathrm{Ga}$ dolerite dykes. These dykes have geochemical features resembling those of within-plate basalts and are consistent with an intracontinental extensional rift setting (Zhao et al. 2010; Zhao and Zhou 2011). Records from both sedimentary and igneous rocks support that the western Yangtze Block was in a continental-rift setting at $\sim 1.7 \mathrm{Ga}$. These observations suggest that the Paleoproterozoic tectonic evolution of the Yangtze Block can be correlated with the assembly and breakup of the Columbia supercontinent.

Previous studies have shown that SSC deposits worldwide formed mostly in late Neoproterozoic and Permian continental rift basins, coincident with the breakup of the Rodinia and Pangea supercontinents, respectively (Brown 1997; Hitzman et al. 2010). Both time periods are marked by extensive evaporite deposition and major global glacial events (Hitzman et al. 2010; Warren 2010), which are thought to be important in ore formation. Such a link between large-scale SSC mineralization and the supercontinental cycle has also been suggested to apply to the late Paleoproterozoic (Hitzman et al. 2010). In the early Paleoproterozoic, a major oxidation event led to the formation of the oldest red beds (Holland 2006; Campbell and Allen 2008), a prerequisite for the formation of SSC deposits (Kirkham 1989; Brown 1997; Hitzman et al. 2010). This implies great potential for SSC deposits during the breakup of the Columbia supercontinent. The copper deposits in the Paleoproterozoic Kodaro-Udokan basin of Siberia were possibly formed during this event (Hitzman et al. 2010). However, the paucity of age data for the Udokan basin makes it difficult to understand its evolutionary history.

Identification of the late Paleoproterozoic SSC deposits in South China provides evidence for a temporal link between the formation of SSC deposits and the initial fragmentation of the Columbia supercontinent. This study highlights the temporal and likely genetic links between large-sized SSC deposits and the supercontinent cycle. An additional implication is that continental blocks that once were part of Columbia, notably where rift basins developed in such blocks, may have potential to host contemporaneous SSC deposits.

\section{Conclusions}

Zircon $\mathrm{U}-\mathrm{Pb}$ and $\mathrm{Cu}$-sulfide $\mathrm{Re}-\mathrm{Os}$ dating from the Yinmin deposit suggest that the "Dongchuan-type" $\mathrm{Cu}$ deposits in South China were formed in the late Paleoproterozoic. These deposits likely represent one of the oldest large-scale SSC mineralization events on Earth. This study provides unequivocal geochronological evidence for the existence of Paleoproterozoic SSC deposits and demonstrates their temporal link to the initial breakup of the Columbia supercontinent.

Acknowledgments This study was supported by the Research Grant Council of Hong Kong (HKU707210P and HKU 707511P) and the financial support for the Chemical Geodynamics Joint Laboratory from Croucher Foundation between HKU and GIGCAS. We thank Mr. Li Liang and Huang Xiaowen for their assistance in zircon U-Pb dating and $\mathrm{Re}-\mathrm{Os}$ isotopic analysis, respectively.

Open Access This article is distributed under the terms of the Creative Commons Attribution License which permits any use, distribution, and reproduction in any medium, provided the original author(s) and the source are credited.

\section{References}

Brown AC (1997) World-class sediment-hosted stratiform copper deposits: characteristics, genetic concepts and metallotects. Aust J Earth Sci 44:317-328

Campbell IH, Allen CM (2008) Formation of supercontinents linked to increases in atmospheric oxygen. Nature Geoscience 1:554-558 
Chang X, Zhu B, Sun D, Qiu H, Zou R (1997) Isotope geochemistry study of Dongchuan copper deposits in Middle Yunnan Province, SW China: stratigraphic chronology and application of geochemical exploration by lead isotopes. Geochimica 26:32-38 (in Chinese with English abstract)

Du A, Wu S, Sun D, Wang S, Qu W, Markey R, Stain H, Morgan J, Malinovskiy D (2004) Preparation and certification of Re-Os dating reference materials: molybdenites HLP and JDC. Geostand Geoanal Res 28:41-52

Gong L, He Y, Chen T (1996) Proterozoic Dongchuan-type rift Cu deposit in Yunnan. Metallurgical Industry, Beijing

Hitzman MW, Kirkham R, Broughton D, Thorson J, Selley D (2005) The sediment-hosted stratiform copper ore system In: Hedenquist JW, Thompson JFH, Goldfarb RJ, Richards JP (eds) Econ Geol pp 609-642

Hitzman MW, Selley D, Bull S (2010) Formation of sedimentary rockhosted stratiform copper deposits through earth history. Econ Geol 105:627-639

Holland HD (2005) Sedimentary mineral deposits and the evolution of earth's near-surface environments. Econ Geol 100:1489-1509

Holland HD (2006) The oxygenation of the atmosphere and oceans. Philosophical Transactions of the Royal Society B-Biological Sciences 361:903-915

Hua R (1990a) The sedimentation-reworking genesis of Dongchuan-type stratiform copper deposits. Chinese J Geochem 9:231-243

Hua RM (1990b) On the Kunyang Aulacogen. Acta Geol Sin 64 (289):301 (in Chinese with English abstract)

Kirkham RV (1989) Distribution, setting, and genesis of sediment-hosted stratiform copper deposits In: Boyle RW, Brown AC, Jefferson CW, Jowett EC, Kirkham RV (eds) Sediment-hosted stratiform copper deposits. Geological Association of Canada, pp 3-38

Peng P, Zhai MG, Ernst RE, Guo JH, Liu F, Hu B (2008) A 1.78 Ga large igneous province in the North China craton: the Xiong'er volcanic province and the North China dyke Swarm. Lithos 101:260-280

Peng M, Wu YB, Wang J, Jiao WF, Liu XC, Yang SH (2009) Paleoproterozoic mafic dyke from Kongling terrain in the Yangtze Craton and its implication. Chinese Sci Bull 54:1098-1104

Qiu HN, Zhu BQ, Sun DZ (2002) Age significance interpreted from 40Ar/39Ar dating of quartz samples from the Dongchuan Copper Deposits, Yunnan, SW China, by crushing and heating. Geochem J 36:475-491

Ran CY (1989) Dongchuan-type stratabound copper deposits, China: a genetic model In: Boyle RW, Brown AC, Jefferson CW, Jowett EC, Kirkham RV (eds) Sediment-hosted stratiform copper deposits. Geological Association of Canada, pp 667-677

Rogers JJW, Santosh M (2002) Configuration of Columbia, a Mesoproterozoic supercontinent. Gondwana Res 5:5-22

Ruan HC, Hua RM, Cox DP (1991) Copper deposition by fluid mixing in deformed strata adjacent to a salt diapir, Dongchuan Area, Yunnan Province, China. Econ Geol 86:1539-1545
Stein HJ, Morgan JW, Scherstén A (2000) Re-Os dating of low-level highly radiogenic (LLHR) sulfides: the Harnäs gold deposit, Southwest Sweden, records continental-scale tectonic events. Econ Geol 95:1657-1671

Sun M, Chen N, Zhao G, Wilde SA, Ye K, Guo J, Chen Y, Yuan C (2008) U-Pb Zircon and Sm-Nd isotopic study of the Huangtuling granulite, Dabie-Sulu belt, China: Implication for the Paleoproterozoic tectonic history of the Yangtze Craton. Am J Sci 308:469-483

Warren JK (2010) Evaporites through time: tectonic, climatic and eustatic controls in marine and nonmarine deposits. Earth-Sci Rev 98:217-268

Wu M-D, Duan J-S, Song X-L, Chen L, Dan Y (1990) Geology of Kunyang Group in Yunnan Province. Scientific Press of Yunnan Province, Kunming

Wu Y-B, Zheng Y-F, Gao S, Jiao W-F, Liu Y-S (2008) Zircon U-Pb age and trace element evidence for Paleoproterozoic granulite-facies metamorphism and Archean crustal rocks in the Dabie Orogen. Lithos 101:308-322

Xiong Q, Zheng JP, Yu CM, Su YP, Tang HY, Zhang ZH (2009) Zircon $\mathrm{U}-\mathrm{Pb}$ age and $\mathrm{Hf}$ isotope of Quanyishang A-type granite in Yichang: signification for the Yangtze continental cratonization in Paleoproterozoic. Chinese Sci Bull 54:436-446

Ye L, Liu Y-P, Li C-Y, Liu J-J (2004) The Ar-Ar isotopic age in Dongchuan Taoyuan type copper deposit, Yunnan Province and its significance. Journal of Mineralogy and Petrology 24:57-60 (in Chinese with English abstract)

Zhang S-B, Zheng Y-F, Wu Y-B, Zhao Z-F, Gao S, Wu F-Y (2006) Zircon $\mathrm{U}-\mathrm{Pb}$ age and $\mathrm{Hf}-\mathrm{O}$ isotope evidence for Paleoproterozoic metamorphic event in South China. Precambrian Res 151:265-288

Zhao X-F, Zhou M-F (2011) Fe-Cu deposits in the Kangdian region, SW China: a proterozoic IOCG (iron-oxide-copper-gold) metallogenic province. Miner Deposita 46:731-747

Zhao G, Cawood PA, Wilde SA, Sun M (2002) Review of global 2.1$1.8 \mathrm{Ga}$ orogens: implications for a pre-Rodinia supercontinent. Earth-Sci Rev 59:125-162

Zhao G, Sun M, Wilde SA, Li S (2004) A Paleo-Mesoproterozoic supercontinent: assembly, growth and breakup. Earth-Sci Rev 67:91-123

Zhao T-P, Chen W, Zhou M-F (2009) Geochemical and Nd-Hf isotopic constraints on the origin of the 1.74-Ga Damiao anorthosite complex, North China Craton. Lithos 113:673-690

Zhao X-F, Zhou M-F, Li J-W, Sun M, Gao J-F, Sun W-H, Yang J-H (2010) Late Paleoproterozoic to early Mesoproterozoic Dongchuan Group in Yunnan, SW China: Implications for tectonic evolution of the Yangtze Block. Precambrian Res 182:57-69

Zhao X-F, Zhou M-F, Hitzman MW, Li J-W, Bennett M, Meighan C, Anderson E (2012) Late paleoproterozoic to early mesoproterozoic tangdan sedimentary rock-hosted strata-bound copper deposit, Yunnan Province, Southwest China. Econ Geol 107:357-375 